American Journal of Applied Sciences 6 (1): 114-123, 2009

ISSN 1546-9239

(C) 2009 Science Publications

\title{
Analysis of the Effect of Pile Skin Resistance Verses Pile Diameter Based on Experimental Research
}

\author{
${ }^{1}$ S.M. Marandi and ${ }^{2}$ M.A. Karimzadeh \\ ${ }^{1}$ Department of Civil Engineering, Bahonar University, Kerman, Iran \\ ${ }^{2}$ Civil Engineer Senior Expert, Shiraz, Iran
}

\begin{abstract}
In spite of the many recent advances in pile design and execution methods, the quantitative effects of grouted pile skin resistance and form on subsequent pile behavior remains an area for research. There are many parameters involved in the analysis of the bearing capacity of piles and descriptive method theory of the loading effect for each parameter is very complex. Many of these parameters are interrelated and investigation of the relationships leads to complex equations, which cannot be easily solved. The only reliable solution is to study the influence of each parameter by experimental model tests in equipped laboratories. This research presents the results of static compression tests on two model groups of pipe and grouted pile shafts $(35 \mathrm{~mm}, 50 \mathrm{~mm}$ and $60 \mathrm{~mm}$ in diameters and $900 \mathrm{~mm}$ in length) installed into beds of Yazd siliceous sand (located in southeast Iran). The findings of the experimental research were to the average ultimate loads at failure for grouted piles were approximately $12 \%$ higher than for the pipe piles. The pile skin resistance is an effective factor on pile bearing capacity, the load transfer response appears to be more plastic with increasing pile diameter in siliceous sand and the skin resistance of the pile was not linearly proportional to the pile diameter and varied with increase in pile diameter.
\end{abstract}

Key words: Sand, laboratory model, grouting pile, skin resistance

\section{INTRODUCTION}

There are numerous interrelated parameters that influence the axial behavior of a pile subjected to axial load. Leland ${ }^{[1]}$ summarized the key parameters including type of loading, soil, pile characteristics and installation methods. However, in spite numerous experimental investigations and theoretical analysis, new data are believed to provide a better insight into the behavior of grouted piles and pipe piles in siliceous sand which; may be considered in future theoretical analysis. This research concentrates on the strength derived from pile roughness and skin resistance with the surrounding soil, which, are two of the main aspects that influence the behavior of piles and requires further attention.

The mechanical behavior of silica sands has been studied for some time and it is reported by Chua ${ }^{[2]}$ and Yeung and Carter ${ }^{[3]}$ that, unlike calcareous sands, they are generally dilatants materials, except when in a very loose condition or when subjected to very high confining pressures. Because of their dilatants nature, silica sands usually develop higher skin frictions and higher bearing capacities than calcareous sands at the same confining pressure.

Pile skin resistance represents the major component in the total pile capacity. Many researches have been carried out in this area. Poulos ${ }^{[4]}$ reported that, the loss of frictional capacity is dependent on several factors, including the load magnitude, which the pile is subjected and the density, over-consolidation ratio and compressibility of the soil.

Tabucanon et al. ${ }^{[5]}$ worked on pile skin friction in sands and reported that, when the piles are subjected to loading, failure can occur in some sandy soils due to a reduction in the shaft friction capacity. For offshore piles and for drilled shafts this degradation of shaft friction is an important consideration.

Joer et al. ${ }^{[6]}$ reported that, the friction capacity of driven piles in calcareous soils tends to be very low, owing to severe reduction of the normal effective stresses at the pile-soil interface during installation of the pile, caused by densification of the soil. The shaft capacity may be increased by injection of grout along the pile-soil interface, referred to as grouted driven pile construction.

Corresponding Author: Seyed Morteza Marandi, 22 Bahman Blvd. Department of Civil Engineering, Bahonar University, P.O.Box 76175-133, Kerman, Iran Tel/Fax: + (98) 341-2462722 Mob: + (98) 913-1404195 
Am. J. Applied Sci., 6 (1): 114-123, 2009

Skin friction on the pile shaft develops as a result of relative displacement between the pile and the surrounding soil. When the vertical downward displacement of a certain part of the pile is larger than the vertical settlement of the surrounding soil, the skin friction on the pile shaft develops and this frictional force contributes to the bearing capacity of the pile.

Grouted piles are a common pile type used due to their ease of installation, longevity, cost effectiveness and the increased skin friction. The research into the effect of skin resistance of grouted piles and the soil type on bearing capacity is studied using experimental research. In order to investigate the effects of skin resistance, a series of static compression tests are conducted on two types of piles; "smooth" surface steel piles and grouted piles (i.e., with a "rough" surface) and the results are compared to establish theoretical models. Previous research into the behavior of grouted piles has been conducted by authors such as: Nutt and Watt ${ }^{[7]}$, Lee and Poulos ${ }^{[8]}$, Poulos and Lee ${ }^{[9]}$ and Randolph ${ }^{[24]}$. These investigations have contributed greatly to the understanding of grouted piles; however, the research has been limited due to the experimental regime of casting the grouted piles in a casing thus producing an unrealistically smooth pile surface and effectively reducing the friction advantages of a grouted pile cast insitu, etc. The main objective of this research is to study the pile skin resistance characteristics of grouted insitu piles in siliceous sands.

\section{EXPERIMENTAL APPARATUS AND PROCEDURE}

Soil characteristics: The material used in this research was siliceous sand with $75 \%$ of silica obtained from Yazd desert area in Iran. The soil was classified as uniformly graded sand with the grain size distribution shown in Fig. 1. Index as well as strength properties of the soil are given in Table 1. The test soil minimum and maximum unit weights were determined using a vibrating table (as per ASTM-D4253-93 and ASTMD4254-91). The strength parameters were determined from tri-axial tests (as per ASTM-D3080).

Consolidation vessel: The pile testing was carried out in a sand box with dimensions of $750 \times 650 \times 1200$ millimeters. In order to minimize the friction between the reservoir wall and the sand, stainless steel plates used for reservoir walls. Based on experiences documented by Lee and Poulos ${ }^{[10]}$ and because of skin friction between the test soil and reservoir wall, the reservoir was constructed with flexible walls to eliminate the heterogeneous distribution of vertical
Table 1: Properties of the Test Soil

\begin{tabular}{llllll}
\hline$\gamma_{\min }\left(\mathrm{kN} / \mathrm{m}^{3}\right)$ & $\gamma_{\max }\left(\mathrm{kN} / \mathrm{m}^{3}\right)$ & $\gamma_{\mathrm{d}}\left(\mathrm{kN} / \mathrm{m}^{3}\right)$ & $\mathrm{D}_{\mathrm{r}}(\%)$ & $\mathrm{PI}(\%)$ & $\mathrm{C}^{\prime}($ degree $)$ \\
\hline 14.42 & 15.70 & 15.40 & 78 & $\mathrm{NP}$ & 0 \\
$\mathrm{D}_{10}(\mathrm{~mm})$ & $\mathrm{D}_{30}(\mathrm{~mm})$ & $\mathrm{D}_{60}(\mathrm{~mm})$ & $\mathrm{C}_{\mathrm{c}}$ & $\mathrm{C}_{\mathrm{u}}$ & $\varphi^{\prime}($ degree $)$ \\
0.27 & 0.40 & 0.55 & 1.08 & 2.04 & 33 \\
\hline
\end{tabular}

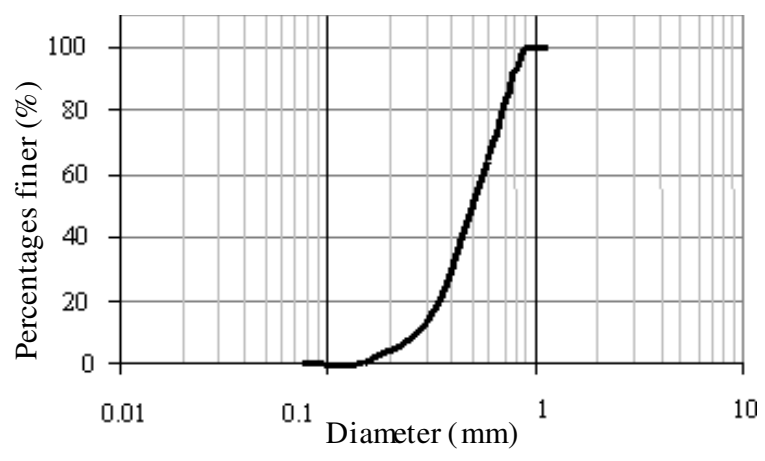

Fig. 1: Grain distribution of test soil

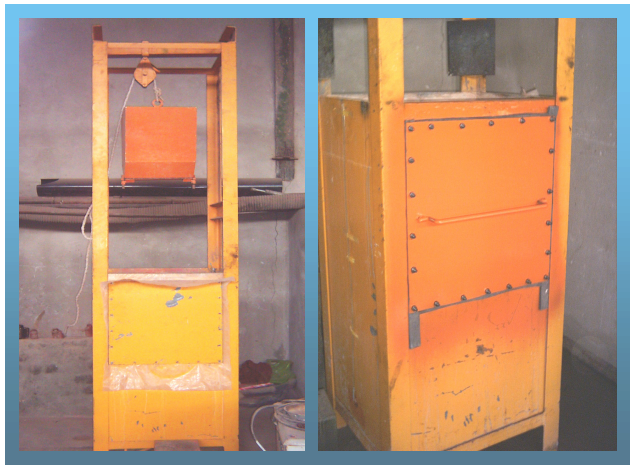

Fig. 2: Schematic sketch of test reservoir

stress at depth. Based on zone of influence of the pile, it was felt that the use of rigid walls around the reservoir might have caused dilation in grain soil during pile loading. A photograph of the box is given in Fig. 2.

The schematic sketch description of the box is given in Fig. 3. A frame with four mounted angles of $100 \times 100$ millimeters and approximate length of 3000 millimeters was constructed at the reservoir corners. This frame had the purpose of assisting with structural stability of the reservoir, as a support for the process of filling the reservoir and, provided the anchor point for loading the piles. The various parts of the reservoir shown in Fig. 2 were: (1) reservoir door, (2) water level monitor, (3) support beams for loading, (4) erection tools support and (5) supporting beams for filling the reservoir.

Preparation of soil medium: The primary process for preparation of the sample for the testing program was 


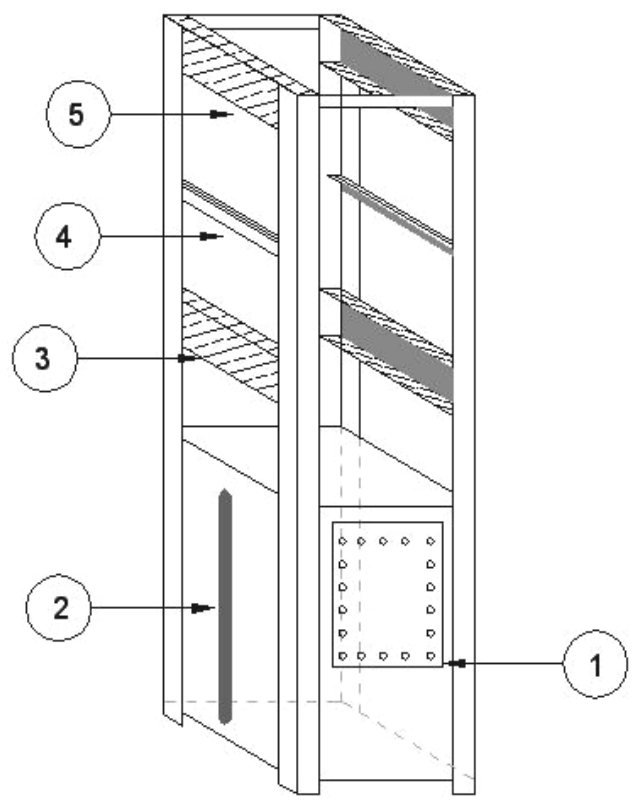

Fig. 3: Schematic sketch of test frame and reservoir

filling the reservoir with sand material. The sand was rained from a constant height (Foray and Balachowski, $)^{[11]}$ into the vessel so that it should have a relatively constant density throughout. To perform this action, a grooved funnel was constructed. With the aid of this funnel, the falling height and also area of placement was controlled. The vertical movement of the funnel was controlled by rope and pulley and the horizontal movements controlled by guide rails. In this research the fall height was 750 millimeters and the relative density achieved was $78 \%$.

The sand was saturated and initially consolidated prior to pile installation with a pressure equal to the final test overburden pressure. After consolidation was complete, the consolidation pressure was removed to allow construction of the grouted pile.

The installation of the piles was made under saturated conditions to achieve consistency in sand density, water content and general installation conditions. Once the sand had been placed in the reservoir, the sample was saturated completely (note that to prevent leakage from the reservoir, all junctions within the reservoir bow were sealed with silicon adhesive). As the testing was to be conducted under drained conditions, after installation of the piles with discharge valve being left open, the reservoir was drained completely (Fig. 4). Soil testing just prior to the commencement of testing when all procedures were made, water content of the sand material was less than $3 \%$.

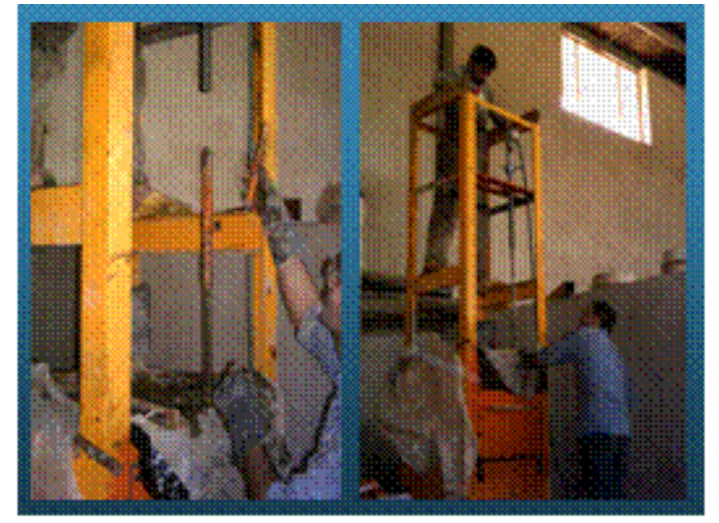

Fig. 4: Schematic sketch of test frame

\section{FABRICATION/CONSTRUCTION OF THE PILES}

Piles used for this research were divided in two groups consisting of pipe piles (PP) and grouted piles (GP). The grouted piles were constructed using penetration of cement slurry. To enable comparison and analysis of the performance between the different types of piles three diameters, $35 \mathrm{~mm}, 50 \mathrm{~mm}$ and $60 \mathrm{~mm}$ diameter piles were used, all with a length of $900 \mathrm{~mm}$ (Table 2 and Fig. 5). The selection of pile dimensions was made based on laboratory facilities and information obtained from previous research.

To facilitate the installation of the piles, grooves were lathed into the pile tip (cone) a spiral pattern rotating in direction of pile twisting (refer to the following chapter for details on pile installation, Fig. 6).

In the production of grouted piles, steel tubes were used as the core for the pile and a steel head tip similar to that explained for steel pipe was used. Immediately behind the pile tip were located punching paddle blades surrounding the core tube to enable the grouting materials flow in such a way as to produce a consistent grouted piles (Fig. 7). As the pile was penetrated into the soil medium a hand pump was used to inject the grout slurry into the core tube, thus into the area surrounding the core tube with no outer casing, to form the grouted pile. The grout slurry had a water-cement ratio of 0.6.

Design of the Grouted Pile Core and Grouted Delivery System: The design of the grouted pile core and delivery system was critical to the experimental work as the more consistent the final pile, the better the comparison and analysis between the pipe and grouted piles. In a previous method used by Lee and Polous ${ }^{[10]}$, a metal drill of $47 \mathrm{~mm}$ diameter was used as an auger to bore a hole to the required depth with the aid of a 
Am. J. Applied Sci., 6 (1): 114-123, 2009

Table 2: Summary of load-controlled tests

\begin{tabular}{|c|c|c|c|c|c|c|c|c|c|c|c|}
\hline $\begin{array}{l}\text { Test } \\
\text { pile } \\
\text { No. }\end{array}$ & $\begin{array}{l}\text { Real pile } \\
\text { diameter } \\
(\mathrm{mm})\end{array}$ & $\begin{array}{l}\text { Pile tip } \\
\text { diameter } \\
\left(\mathrm{mm}^{2}\right)\end{array}$ & $\begin{array}{l}\text { Pile tip } \\
\text { area } \\
\left(\mathrm{mm}^{2}\right)\end{array}$ & $\begin{array}{l}\text { Hansen } \\
\text { coefficient } \\
(\mathrm{Nq})\end{array}$ & $\begin{array}{l}\text { Hansen } \\
\text { coefficient } \\
\text { (dq) }\end{array}$ & $\begin{array}{l}\text { Meyerhof } \\
\text { coefficient } \\
\left(\mathrm{N}_{\mathrm{q}}^{*}\right)\end{array}$ & $\begin{array}{l}\text { Total } \\
\text { bearing load } \\
\text { (N) }\end{array}$ & $\begin{array}{l}\text { Hansen } \\
\text { point load } \\
(\mathrm{N})\end{array}$ & $\begin{array}{l}\text { Hansen skin } \\
\text { resistance } \\
(\mathrm{N})\end{array}$ & $\begin{array}{l}\text { Meyerh of } \\
\text { point load } \\
\text { (N) }\end{array}$ & $\begin{array}{l}\text { Meyerh of } \\
\text { skin resistance } \\
\text { (N) }\end{array}$ \\
\hline$\overline{\text { GP35-1 }}$ & 40.7 & 35 & 961 & 26.3 & 1.41 & 100 & 4022 & 505 & 3517 & 1358 & 2664 \\
\hline GP35-2 & 41.1 & 35 & 961 & 26.3 & 1.41 & 100 & 5003 & 505 & 4498 & 1358 & 3645 \\
\hline GP50-1 & 56.1 & 58 & 2640 & 26.3 & 1.41 & 100 & 4218 & 1381 & 2837 & 3731 & 487 \\
\hline GP50-2 & 58.2 & 54 & 2289 & 26.3 & 1.41 & 100 & 5199 & 1197 & 4002 & 3233 & 1966 \\
\hline GP60-1 & 65.8 & 65 & 3316 & 26.3 & 1.40 & 100 & 6671 & 1731 & 4940 & 4685 & 1986 \\
\hline GP60-2 & 67.5 & 65 & 3316 & 26.3 & 1.40 & 100 & 6867 & 1731 & 5136 & 4685 & 2182 \\
\hline PP35-1 & 35 & 35 & 961 & 26.3 & 1.41 & 100 & 3041 & 505 & 2536 & 1358 & 1683 \\
\hline PP35-2 & 35 & 35 & 961 & 26.3 & 1.41 & 100 & 2943 & 505 & 2438 & 1358 & 1585 \\
\hline PP50-1 & 50 & 50 & 1962 & 26.3 & 1.41 & 100 & 4267 & 1079 & 3188 & 2772 & 1495 \\
\hline PP50-2 & 50 & 50 & 1962 & 26.3 & 1.41 & 100 & 3826 & 1079 & 2747 & 2772 & 1054 \\
\hline PP60-1 & 60 & 60 & 2826 & 26.3 & 1.40 & 100 & 4120 & 1475 & 2645 & 3992 & 128 \\
\hline PP60-2 & 60 & 60 & 2826 & 26.3 & 1.40 & 100 & 4415 & 1475 & 2940 & 3992 & 423 \\
\hline
\end{tabular}

$\mathrm{d}_{\mathrm{q}}$ :depth effective coefficient

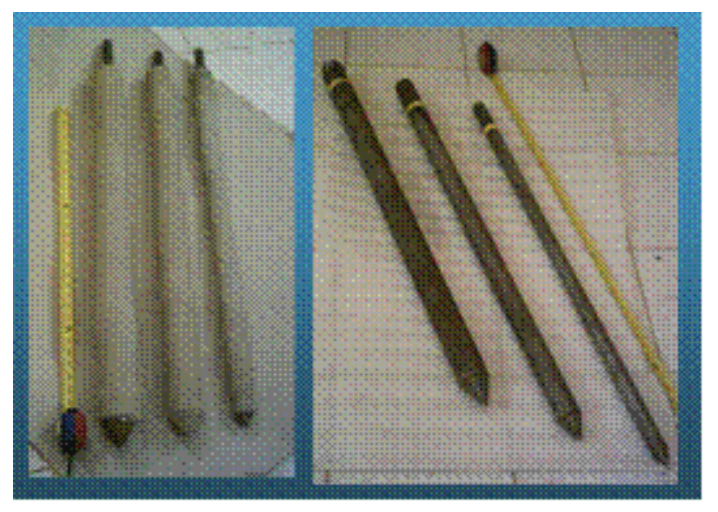

Fig. 5: Two groups of steel and grouted piles

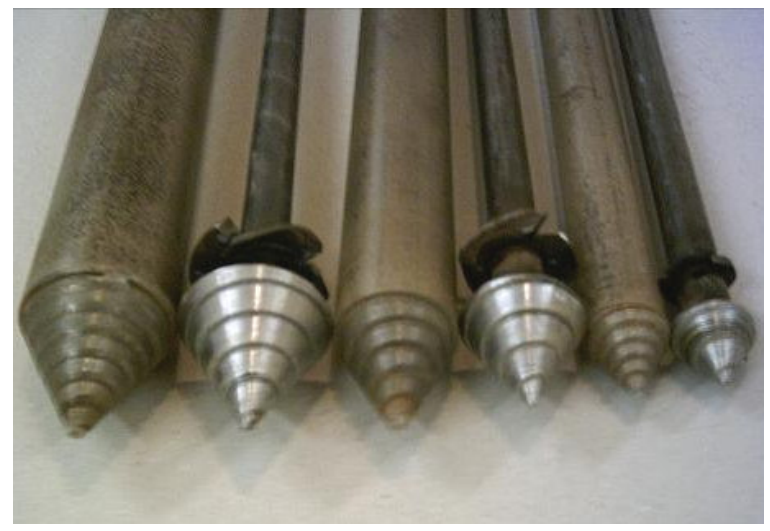

Fig. 6: Cone tips of the piles

guiding device, which was attached to the center opening of the vessel lid. The drilled hole in the soil was found to stand open without support. The bore hole was then filled with wet grout. After grouting an instrumented aluminum tube was inserted into the wet grout and the surface of the pile was assumed to be uniform due to the presence of the tube.

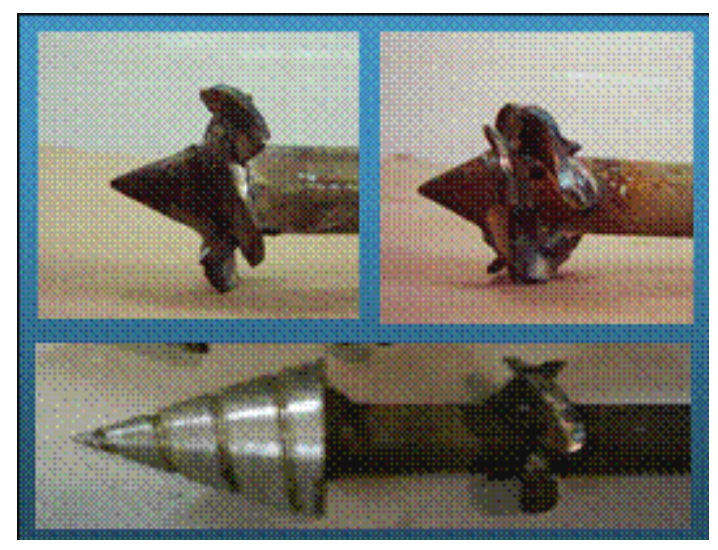

Fig. 7: Various tips of grouting piles

As the aim of this research was to approximate field conditions as closely as possible it was decided to construct the grouted pile as close to field conditions as possible, that meant placing (pumping) the grout into the pile hole during installation of the pile. Historically, when using this procedure it has been difficult to achieve a uniform pile, thus the design of the pile insertion and grouting apparatus was critical to this research.

In order to develop a design to provide the most consistent final grouted pile, three different types of grouting piles were constructed and used. The main difference between the models was the positioning and size, of the paddle blades used for distributing the grout mixture behind the pile tip (Fig. 7).

To optimize the position of paddle blades in relate to punch holes and, to eliminate the clogging during the execution of grout penetration, several tests carried out. The results showed that, the positioning the paddle blades, immediately behind the pile cap provided the best results and provided uniformity in the final grouted pile that was suitable for use in the experimental tests. 
On extraction after the tests, the grouted pile surface was found to be quite uniform (Fig. 5) and thus it was reasonable to assume that the grout penetration into the surrounding soil due to the core tube penetration was negligible. The proof of this procedure was shown in the resultant pile diameters and the fact that the reservoir discharge did not contain traces of the cement slurry. The grouted piles were then allowed to cure under these conditions for at least four days before testing (as suggested by Lee and Poulos) ${ }^{[10]}$.

Installation of the Piles: The method of twisting was used for installation of the model piles. Selection of this method was due to conditions and benefits as follows:

- The method is reliable for grouted piles; and; achieves a continuous surface

- In granular saturated soils (sand), which are susceptible to liquefaction, this method is preferred to hammer methods

As the testing was being conducted in a contained medium (the reservoir) and several piles were being inserted at the same time, the positioning of the piles was an important factor in the testing regime. The installation of a pile in sand or any other granular soil displaces and compacts the soil surrounding the soil. Much research has been carried out on the extent of the effected zone surrounding a single pile installed in granular soils (Meyerhof ${ }^{[12]}$, Kishida ${ }^{[13]}$ and Robinsky and Morrison $\left.{ }^{[14]}\right)$. The results of these studies confirmed the generally the accepted trends (Poulos and Davis ${ }^{[15]}$ ) as discussed below.

When a pile with diameter of B penetrates sand, the surrounding sand displaces; and a failure area is established resulting in, shear in a cylindrical shape with a diameter of a. This action causes a larger compacted area with diameter of $b\left(\right.$ Whitaker $\left.{ }^{[16]}\right)$. For loose sands Meyerhof introduced the following limits (Leland and $\mathrm{Kraft}^{[1]}$ ):

$$
a=4 B, b=6 B \text { to } 8 B
$$

Kersel proposed the following limits of $\mathrm{a}$ and $\mathrm{b}$ for compacted sands (Kersel, 1961 ${ }^{[17]}$ ):

$$
a=3 B, b=6 B
$$

In this experimental research, for more confidence, the maximum effective radius used is $7 \mathrm{~B}$. Based on this information the piles were arrangement in the reservoir vessel is shown in Fig. 8.

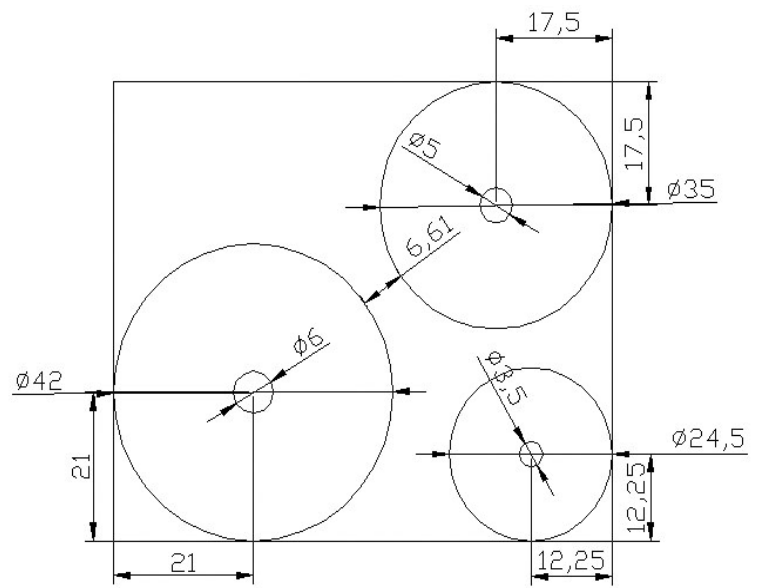

Fig. 8: Displacement of piles and compaction area for each pile (values in $\mathrm{cm}$ )

Load testing the piles: The process of loading the piles was based on ASTM D-1143. According to this specification, the load is applied by a jack mounted on the rig (reservoir frame) which is raised to a constant value and kept constant during the testing.

Mobilization of the ultimate point resistance in any soil requires a point displacement on the order of 10 percent of the tip diameter for driven piles (Bowles ${ }^{[18]}$, Tomlinson ${ }^{[19]}$ ). The criterion chosen for the testing program was a displacement equivalent to $10 \%$ of the pile diameter; at which point the ultimate point loads were calculated.

To ensure that the applied load resulted in a net axial loading on the pile, that eccentricity was maintained and that no moments developed on the pile, the load was applied through a circular steel plate of $160 \mathrm{~mm}$ diameter and $33 \mathrm{~mm}$ thickness. The plate was lathed and constructed with concentric grooves equivalent to the testing piles.

The grooves were lathed in such a way that; the plate sat on top of the pile easily; and on the other center side of the plate; a semi-sphere hole was lathed to position the load lever. In this case, the connection of the load lever with the plate acted as a complete hinge and prevented the creation of any moments on top of the pile.

A loading lever was positioned between the load cell and the loading plate. This lever was constructed to enable a screw connection to the load cell and the other side consisted of a sphere to sit in the bowl hole of the plate loading.

Based on ASTM specification, a glass sheet was used to position the gauges stems and to measure the pile displacement. 
To monitor the pile-loading system, a load cell was used. The ultimate capacity of the cell was $9810 \mathrm{~N}$ $(1000 \mathrm{~kg})$ and was produced by the Bongshin Factory (Iran). A digitizer read the output data. The resolution of the digitizer could be set and was varied between 1 to 200 grams.

To determine the pile displacement, two clock gauges with resolution of $0.05 \mathrm{~mm}$ were used. The stem length of the gauges was $50 \mathrm{~mm}$; and; their use was based on ASTM specification. The gauges were positioned at equal distance from the center of the pile; along the longitudinal axis and fixed in place using a magnetic clamp.

A box section steel beam frame was used to halter the jack reaction in the reservoir-testing rig. Due to the beam dimensions; and; in relation to the applied loads, the beam acted as a fixed point. With positioning the beam reaction into the constructed rails; the reactions were transformed from the jack to the frame of the rig.

To apply the compressive load on the piles; a gear jack with a maximum displacement of $40 \mathrm{~mm}$ was used.

\section{EXPERIMENTAL RESULTS}

The results of the pile load tests, including pile dimensional data is shown in Table 2. In this table, the pipe piles and grouted piles are identified by "PP" and "GP" respectively. Also the grouted piles diameters are the average measured diameters after extraction.

Cone tips with a vertex angle of 60 degrees were used in all piles to minimize the effect of point strength. In this work, the grouted piles ended up being of a slightly greater diameter than the pipe piles; this would result in a greater capacity for tip load. However, due to identical pile tips, the increase in pile bearing capacity appears to be in relating to increase in skin resistance.

To evaluate the effect of skin resistance on pile bearing capacity; the tip resistance and skin resistance were separated. The method of separation of the different forces was based on estimating the tip resistance using established theoretical calculations by Meyerhof $^{[20]}$ and Hansen ${ }^{[21]}$.

Both of these methods are based on the addition of tip resistance and skin resistance, found by multiplying the appropriate surface areas by unit resistance. For determination of the skin resistance, the unit point resistance was calculated for both methods and subtracted from the total bearing capacity obtained from the test results.

Meyerhof proposed the following expression for the point bearing capacity:

$$
\mathrm{Q}_{\mathrm{p}(\mathrm{M})}=\mathrm{A}_{\mathrm{p}} \times \mathrm{q}_{\mathrm{p}}=\mathrm{A}_{\mathrm{p}} \times \mathrm{q}^{\prime} \times \mathrm{N}_{\mathrm{q}}^{*}
$$

Where:

$\mathrm{Q}_{\mathrm{p}(\mathrm{M})}=$ Meyerhof point bearing capacity,

$\mathrm{A}_{\mathrm{p}}=$ Area of pile tip,

$\mathrm{q}_{\mathrm{p}}=$ Unit point resistance,

$\mathrm{q}^{\prime}=$ Effective vertical stress at the level of the pile tip

$\mathrm{N}_{\mathrm{q}}{ }^{*}=$ The bearing capacity factor

Hansen suggested another equation to compute the point bearing capacity as follows:

$$
\mathrm{Q}_{\mathrm{p}(\mathrm{H})}=\mathrm{A}_{\mathrm{p}}\left[\eta \times \overline{\mathrm{q}} \times\left(\mathrm{N}_{\mathrm{q}}^{\prime}-1\right) \times \mathrm{d}_{\mathrm{q}}\right]
$$

Where:

$\mathrm{Q}_{\mathrm{p}(\mathrm{H})} \quad=$ Hansen point bearing capacity,

$\mathrm{A}_{\mathrm{p}} \quad=$ Area of pile point effective in bearing,

$\eta \quad=1$,

$\bar{q}=\gamma \times \mathrm{L}=$ Effective vertical (or overburden) pressure at pile point,

$\mathrm{N}_{\mathrm{q}}^{\prime} \quad=$ Bearing capacity factor (may include overburden effect)

$\mathrm{d}=1+2 \tan \phi(1-\sin \phi)^{2} \times(\mathrm{L} / \mathrm{B})$.

Most designers use $\mathrm{N}_{\mathrm{q}}^{\prime}$, not $\left(\mathrm{N}_{\mathrm{q}}^{\prime}-1\right)$, for piles when $\phi>0$ since the factor reduced by 1 is a substantial refinement not justified by estimated soil parameters.

The load-displacement curves for model pipe and grouted piles are presented in Fig. 9. The results show that, the average ultimate loads at failure for the $35 \mathrm{~mm}$, $50 \mathrm{~mm}$ and $60 \mathrm{~mm}$ pile diameters were 3700, 4200 and $6250 \mathrm{~N}$ for grouted piles and 2900, 3700 and $4400 \mathrm{~N}$ for pipe piles respectively. The ratio of total bearing load for grouted and pipe piles $\left(\mathrm{y}_{\mathrm{GP}} / \mathrm{y}_{\mathrm{PP}}\right)$ is presented in Fig. 10. The curves show an average increase ratio of $28 \%$. Also the results indicate the slight increase in $\left(\mathrm{y}_{\mathrm{GP}} / \mathrm{y}_{\mathrm{PP}}\right)$ ratio with increase in pile diameter.

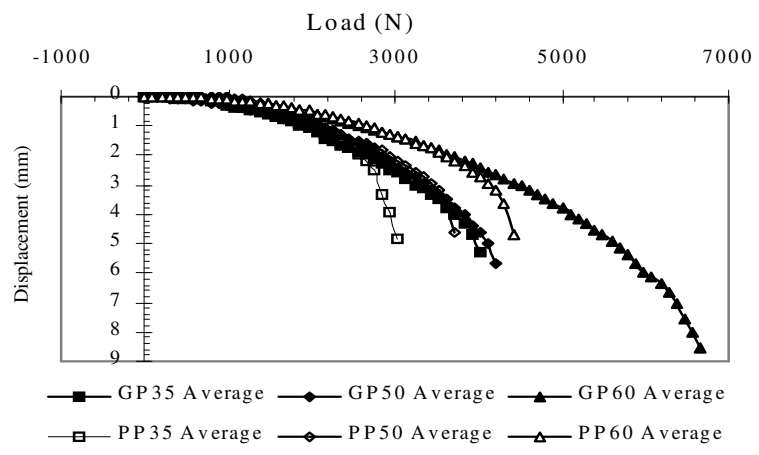

Fig. 9: Static average load curves versus pipe and grouted piles 


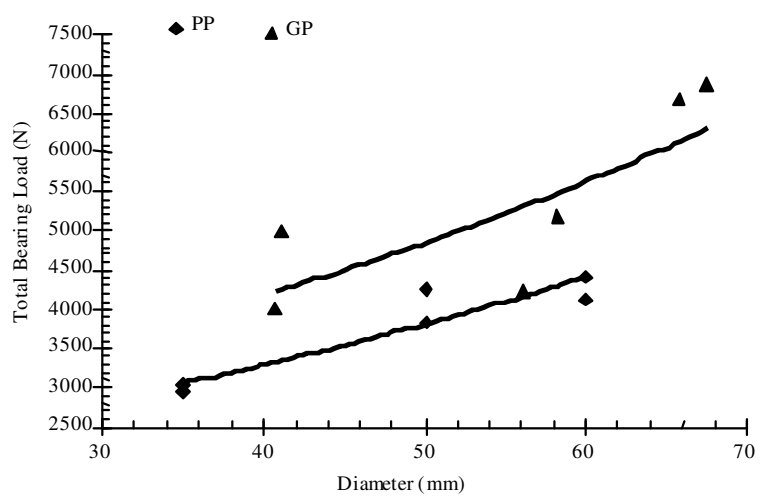

Fig. 10: Total bearing load versus diameter

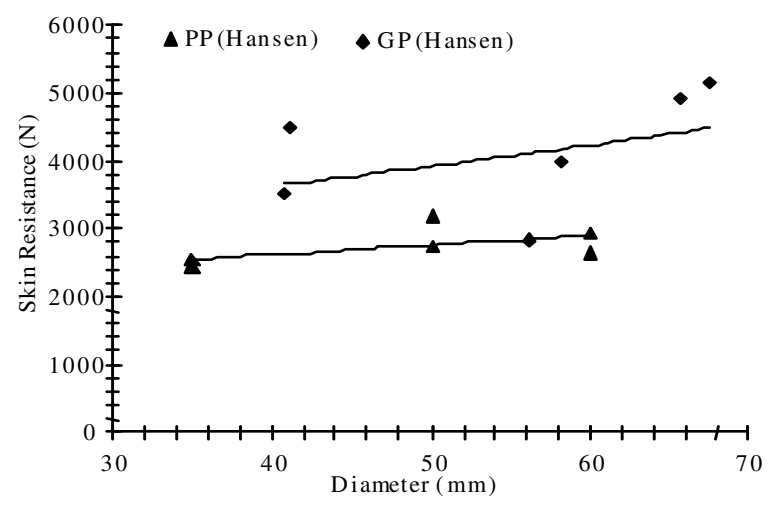

Fig. 11a: Hansen skin resistance versus diameter

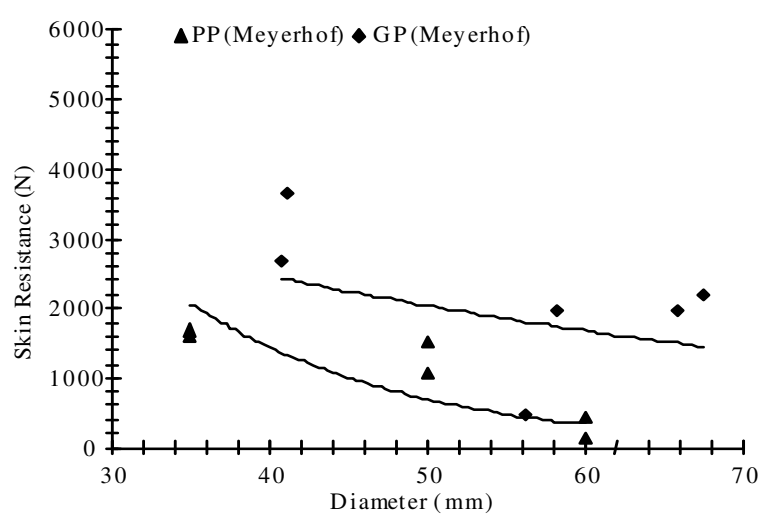

Fig. 11b: Meyerhof skin resistance versus diameter

The resultant skin resistance of the test piles (calculated as discussed above) is given in Table 2 . Typical curves for the $35 \mathrm{~mm}, 50 \mathrm{~mm}$ and $60 \mathrm{~mm}$ grouted and pipe piles are plotted in Fig. 11. Using the Hansen equations the results show that, the skin resistance of grouted piles is higher than for the pipe piles and both decrease with increase in pile diameter.

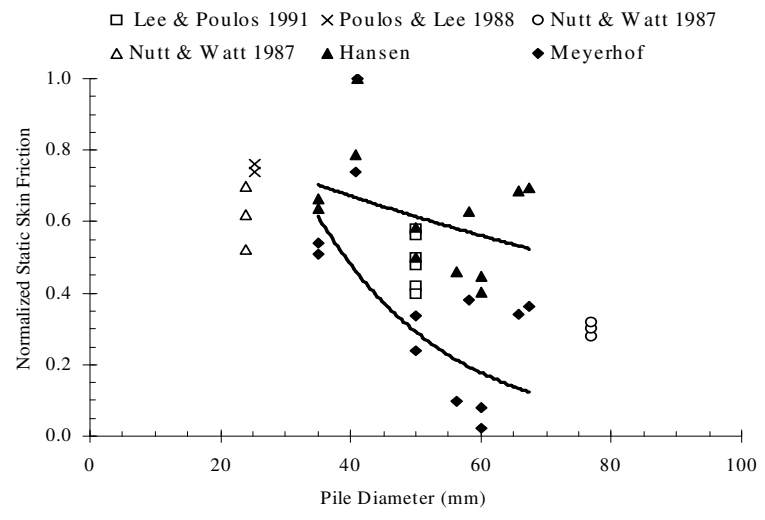

Fig. 12: Effect of pile diameter on static skin friction

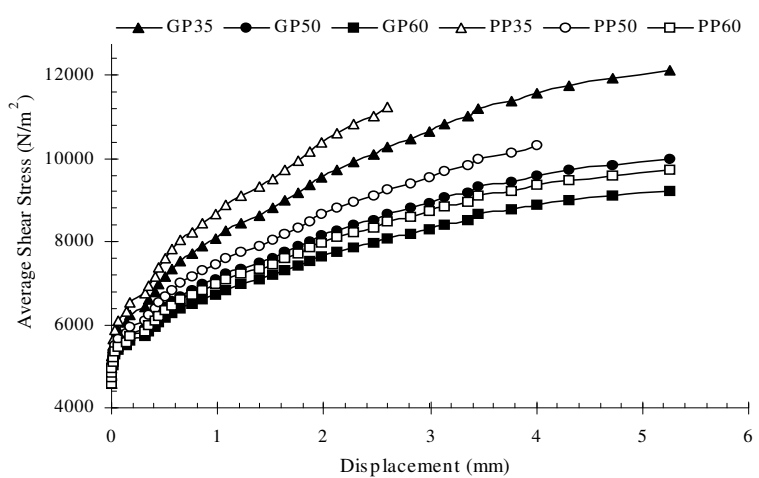

Fig. 13: Typical static average shear stress versus displacement (failure at displacement $=10 \% \mathrm{~d}$ )

Figure 12 shows the normalized static friction $\mathrm{f}_{\mathrm{s}} / \sigma_{\mathrm{v} 0}^{\prime}$ (where, $\mathrm{f}_{\mathrm{s}}$ is skin friction and $\sigma_{\mathrm{v} 0}^{\prime}=$ effective overburden pressure at tip of the pile) versus pile diameters for the present research and the works of other investigators. The plot curves show that; the normalized static skin friction decreases with increase in pile diameter. The present results plot curves indicate that; the decreasing rate of normalized static skin friction with pile diameter is more steep in compare to previous investigations.

The typical static average shear stress-displacement curves for the $35 \mathrm{~mm}, 50 \mathrm{~mm}$ and $60 \mathrm{~mm}$ grouted and pipe piles are plotted in Figure 13. The results show that; with increasing displacement; the average shear stress increases for both grouted and pipe piles.

\section{ANALYSIS AND DISCUSSION OF THE RESULTS}

The load-displacement curves shown in Fig. 9 indicate that; the displacement curves for grouted and pipe piles 
with diameters of 35,50 and $60 \mathrm{~mm}$ are approximately the same up to bearing loads of 2600, 3600 and $3800 \mathrm{~N}$ respectively. Above these loads, the pipe piles curves drop to lower load values in comparison with the grouted piles. Thus the grouted piles have a greater bearing capacity in relation to the pipe piles. Also, as expected, Fig. 10 shows that the larger the pipe diameter the greater the load bearing capacity of the pile. These curves clearly show that; the average ultimate loads at failure for grouted piles are approximately $12 \%$ higher than the pipe piles. The increase in bearing capacity may relate to two factors:

- Pile diameter increase due to penetration of slurry into the sand surrounding the pile and

- Increase of pile skin resistance

The first factor is the natural action of grouted piles and is one of their benefits. The increase in pile diameter depends on slurry, the pressure, density of the soil and the volume of the voids in soil. The experimental procedure of using the rained method achieved a uniform relative density in the sand and by controlling the viscosity of the grout slurry and its pressure the grouted pile diameters were made as uniform as possible (Fig. 5). However; as with any experimental procedure that seeks to mirror site conditions and the nature of porous media, the diameters of the grouted piles were slightly larger than pipe piles (Table 2) and thus it was reasonable to assume that, a slight effect of difference in diameter on the trend of the results was negligible.

Figure 11a-b show that, using Hansen and Meyerhof theoretical methods; there is an increase in skin resistance between the pipe and grouted piles. The results indicate that; the rate of skin resistance of grouted piles to pipe piles $\left(\mathrm{y}_{\mathrm{GP} 35} / \mathrm{y}_{\mathrm{PP} 35}\right)$ is 1.37 , while for $\left(\mathrm{y}_{\mathrm{GP} 50} / \mathrm{y}_{\mathrm{PP} 50}\right)$ and $\left(\mathrm{y}_{\mathrm{GP} 60} / \mathrm{y}_{\mathrm{PP} 60}\right)$ are 1.42 and 1.46 respectively using Hansen theory and, for similar ratios and using Meyerhof theory the ratios are 1.22, 2.74 and 4.71 respectively. It means that, the average increase in ratios between the skin resistance of pipe piles and grouted piles using Meyerhof theory is twofold than that of Hansen theory. For increasing pile diameter the difference between the consecutive skin resistances is also different using above theories. As shown in Fig. $11 \mathrm{a}-\mathrm{b}$, the ratios of the skin resistance of GP50/GP35, GP60/GP50, PP50/PP35 and PP60/PP50 using Hansen theory are $1.12,1.08,1.08$ and 1.05 respectively while, for similar ratios using Meyerhof theory, the ratios are $0.75,0.83,0.33$ and 0.48 respectively. What this means is that, for both grouted and pipe piles; the rates are increasing using Hansen theory while for using the Meyerhof theory the results are reverse.

This controversy appears to be due to the coefficients and soil property index assumptions made in these two theories. The susceptibility to degradation (i.e., reduction) of the skin friction capacity in calcareous sand have been shown by many investigators such as, Poulos and Chan ${ }^{[22]}$, who found from model laboratory jacked pile tests, that piles in calcareous sand suffer more severe degradation of skin friction capacity than piles in silica sand and Nutt and Watt $^{[7]}$ and Poulos and Lee ${ }^{[23]}$ who worked on calcareous sediments and reported that, the pile skin resistance decreases with increase in pile diameter. However, the computed bearing capacity varies widely because there is little agreement on what numerical values to use for the bearing capacity factor $\mathrm{N}_{\mathrm{i}}$.

Despite of slight irregularities in the geometry of the grouted piles and as discussed previously, it is practically impossible to construct an exact grouted pile with exact dimensions, unless using a casing tube, which is in contrast with the scope of this research. However, with the fact that, the test soil used in this research was siliceous sand with relatively uniform density, the skin resistance data obtained using Hansen theory appears to be more reliable in compare to Meyerhof theory.

Typical curves plotted in Fig. 12 show that, the normalized static skin friction decreases with increase in pile diameter. This implies a significant scale effect on pile capacity. Randolph ${ }^{[24]}$ suggested an explanation for such scale effects on skin friction. Moreover, the experimental results obtained for calcareous sand by Nutt and $\mathrm{Watt}^{[7]}$, Poulos and Lee ${ }^{[23]}$ and Lee and Poulos $^{[10]}$ for pile lengths of $600,256,600$ and $644 \mathrm{~mm}$ respectively are presented in Fig. 12 together with the results obtained in present research. The results indicate that, the skin friction of the pile is not linearly proportional to the pile diameter for either calcareous or siliceous sands. The results of this research shows that, the rate of decrease in skin friction with increasing pile diameter for siliceous sand is steeper for both methods of Hansen and Meyerhof in comparison with the results obtained for calcareous sands by other researchers. However; from theoretical view of point is may be true but, friction characteristics suggest that there should be some limiting factor that is related to the friction characteristics between the pile skin and the soil.

Figure 13 indicates that; the grouted; and larger diameter piles appear to be less stiff than the pipe pile and along with the smaller diameter piles tend to exhibit strain-softening behavior which, leads to the 
slight loss of average shear stress. Whereas; the smaller diameter piles appear to exhibit strain hardening. These observations appear to be consistent with Randolph's ${ }^{[24]}$ suggestion that the load transfer response will be more plastic with increasing pile diameter in calcareous soil. Larger diameter piles may show a lower peak shear stress than the smaller diameter piles. Furthermore, it appears that, the behavior of siliceous sand in regard to average shear stress-displacement exhibits the same trend as calcareous sands.

\section{CONCLUSION}

The results of the tests on steel and grouted pile shafts in Yazd siliceous sand revealed the following features:

- The average ultimate loads at failure for grouted piles with diameters of 35,50 and $60 \mathrm{~mm}$ were $12 \%$ greater than pipe piles

- The pile skin resistance for grouted piles was approximately $42 \%$ greater than for the pipe piles (using Hansen theory) while, when using Meyerhof theory there was a twofold increase for consecutive diameters. Overall, the pile skin roughness was found to be an effective factor on pile bearing capacity

- The load transfer response was more plastic with increasing pile diameter in the siliceous desert sand. Larger diameter grouted piles may show a lower peak shear stress than the smaller diameter and pipe piles

- The skin friction of the pile is not linearly proportional to the pile diameter for siliceous desert sand

- The design of the grouted pile installation system achieved good results in final uniformity of the tested pile Improving the shape and positioning of the paddle blades behind the pile head showed that it is possible to conduct experimental research in near field conditions

\section{ACKNOWLEDGMENTS}

We would like to express our sincere appreciation to Jahan Pay Saman Company for providing funds and facilities for this project. Specially, we would like to thank Dr. Mohammed Taghi Izadi for his valuable role during the course of this study.

We also would like to express our sincere appreciation to Ministry of Roads and Transportation Technical Laboratory for carrying out all soil tests necessary for this research.

\section{REFERENCES}

1. Leland, M. Kraft Jr., 1991. Performance of axially loaded pipe piles in sand. J. Geo-Tech. Eng., 117 (2): 272-296.

2. Chua, E.W., 1983. Bearing Capacity of Shallow Foundations in Calcareous Sand. MSc. Thesis. University of Sydney.

3. Yeung, S.K. and J.P. Carter, 1989. An assessment of the bearing capacity of calcareous and silica sands. Int. J. Numerical Anal. Methods Geo-Mech., 13: 19-36.

4. Poulos, H.G., 1989. Cyclic axial loading analysis of piles in sand. J. Geotech. Eng. ASCE, 115 (6): 836-851.

5. Tabucanon, J.T., D.W. Airey and H.G. Poulos, 1995. Pile skin friction in sands from constant normal stiffness tests. Geotech. Test. J. ASTM, 18 (3).

6. Joer, H.A., M.F. Randolph and U. Gunasena, 1998. Experimental modeling of the shaft capacity of grouted driven piles. Geotech. Test. J. ASTM, 21 (3).

7. Nutt, N.R.F. and P.J. Watt, 1987. The analysis of foundations for offshore structures in calcareous deposits. Thesis Presented to the University of Sydney. Sydney, Australia, in Partial Fulfillment of the Requirements for the Degree of Bachelor of Engineering.

8. Lee, C.Y. and H.G. Poulos, 1988. Jacked model pipe shafts in offshore calcareous soils. Mar. Geo-Tech., 7 (4): 247-274.

9. Poulos, H.G. and C.Y. Lee, 1989. Behavior of model grouted piles in offshore calcareous sand. Proceeding 12th International Conference on Soil Mechanic and Foundation Engineering. A.A. Balkema, Rotterdam. The Nederlands, 2: 955-958.

10. Lee, C.Y. and H.G. Poulos, 1991. Tests on model instrumented grouted piles in offshore calcareous soil. J. Geo-Tech. Eng., 117 (11): 1738-1753.

11. Foray, P., L. Balachowski and J.L. Colliat, 1998. Bearing capacity of model piles driven into dense over-consolidated sands. Can. Geo-Tech. J., 35: 374-385.

12. Meyerhof, G.G., 1959. Compaction of sand and bearing capacity of pile. JFMFD, ASCE, 85 (SM6): 1-29.

13. Kishida, H., 1963. Stress distribution by model piles in sand. Soils and Foundations. 4, (1): 1-23.

14. Robinsky, E.I. and C.F. Morrison, 1964. Sand displacement and compaction around model friction piles. Can. Geo-Tech. J., 1 (2): 81-93. 
15. Poulos, H.G. and E.H. Davis, 1980. Pile Foundation Analysis and Design. John Wiley and Sons.

16. Whitaker, Thomas 1976. The Design of Piled Foundations. $2^{\text {nd }}$ Edn. Pergamon Peress.

17. Kersel, J., 1961. Deep foundation in sand variation of ultimate bearing capacity with soil density, depth, diameter and speed of penetration. Proceedings of 50th International Conference in Soil Mechanics. Paris, No.2, pp: 73-84.

18. Bowles, Joseph E., 1996. Foundation Analysis and Design. 5th Edn. Mc-Graw Hill, New York, USA, pp: 1175.

19. Tomlinson, M.J., 1995. Pile Design and Construction Practice. 4th Edn. E and FN Spon Publisher, UK.

20. Meyerhof, G.G., 1976. Bearing capacity and settlement of pile foundations. J. Geo-Tech. Eng. Div. ASCE, New York, U.S.A., 102: 197-228.
21. Hansen, J.B., 1970. A Revised and Extended Formula for Bearing Capacity. Danish Geotechnical Institute, Copenhagen, Bulletin No. pp: 28, 21. (successor to Bulletin No. 11).

22. Poulos, H.G. and K.F. Chan, 1986. Laboratory study of pile skin friction in calcareous sand. Proc. GeoTech. Eng., 17 (2): 235-257.

23. Poulos, H.G. and C.Y. Lee, 1988. Model test on grouted piles in calcareous sediment. International Conference on Calcareous Sediments. A.A. Balkema, Rotterdam, The Nederlands, 1: 255-260.

24. Randolph, M.F., 1988a. The axial capacity of deep foundation in calcareous soil. International Conference on Calcareous Sediments. A.A. Balkema, Rotterdam, The Nederlands, 2: 837-857. 